\title{
Karakteristik Pasien Sirosis Hepatis di RSUP Dr. M. Djamil Padang
}

\author{
Angela Lovena ${ }^{1}$, Saptino Miro ${ }^{2}$, Efrida $^{3}$
}

\begin{abstract}
Abstrak
Sirosis hepatis didefinisikan sebagai penyakit hati kronik yang menyebabkan proses difus pembentukan nodul dan fibrosis pada hati. Di RSUP Dr. M. Djamil Padang sirosis hepatis merupakan salah satu penyakit terbanyak yang dirawat di Bagian Penyakit Dalam. Tujuan penelitian ini adalah menentukan karakteristik pasien sirosis hepatis di RSUP Dr. M. Djamil Padang. Penelitian ini merupakan studi deskriptif observasional dengan menggunakan data rekam medik pasien sirosis hepatis yang dirawat di ruang rawat inap Bagian IImu Penyakit Dalam RSUP Dr. M. Djamil Padang periode 1 Januari 2011 sampai 31 Desember 2013, sehingga didapatkan sampel penelitian sebanyak 304 buah. Data yang diambil yaitu tes serologi untuk hepatitis B dan hepatitis $\mathrm{C}$, kadar albumin, jumlah trombosit, kadar kreatinin serum dan komplikasi sirosis hepatis. Hasil penelitian ini mendapatkan penyebab sirosis hepatis terbanyak virus hepatitis B $(51,0 \%)$, kadar albumin $<3,0 \mathrm{~g} / \mathrm{dl}(71,4 \%)$, jumlah trombosit normal $(48,7 \%)$, kadar kreatinin normal (76,7\%), komplikasi terbanyak asites (36,3\%),dan klasifikasi Child pugh terbanyak adalah Clid pugh C (60,3\%). Simpulan penelitian ini adalah hepatitis B sebagai penyebab tersering, kadar albumin terbanyak adalah <3,0 g/dl, jumlah trombosit terbanyak adalah jumlah trombosit dan kadar kreatinin terbanyak adalah yang normal, asites sebagai komplikasi terbanyak dan klasifikasi terbanyak adalah Child pugh C.
\end{abstract}

Kata kunci: sirosis hepatis, karakteristik pasien

\begin{abstract}
Liver cirrhosis is defined as a chronic liver disease that causes diffuse formation of nodules and fibrosis of the liver. In RSUP Dr. M. Djamil Padang liver cirrhosis is one of the most disease in the internal medicine departement. The objective of this study was to determine the characteristics of patients with liver cirrhosis in RSUP Dr. M. Djamil Padang. This study was an observational descriptive study using medical record data of liver cirrhosis patients in RSUP Dr. M. Djamil Padang from January 2011 until December 2013, samples in this study were 304. The data were serology for hepatitis $B$ and hepatitis $C$, albumin levels, platelet count, serum creatinine, and complications of liver cirrhosis. The results of this study showed that highest proportion in liver cirrhosis patients by age group 51-60 years (35.2\%), male gender (65.8\%), the most common cause is hepatitis B virus infection (51.0\%), albumin level $<3.0 \mathrm{~g} / \mathrm{dl}$ (71,4\%), normal platelet count (48.7\%), normal serum creatinine (76.7\%), with ascites complications (36.3\%), and with the clasification Child-Pugh C (60.3\%). The conclusion of this study were hepatitis $B$ virus is the most common cause, albumin level < 3.0g/dl, normal platelet count and normal serum creatinine are the most common on laboratory test, ascites as common complication and Child-Pugh $C$ is the most common classification.
\end{abstract}

Keywords: liver cirrhosis, patients's characteristics

Affiliasi penulis: 1. Prodi Profesi Dokter FK Unand (Fakultas Kedokteran Universitas Andalas Padang), 2. Bagian IImu Penyakit Dalam FK Unand/RSUP Dr. M. Djamil Padang, 3. Bagian Patologi Klinik FK Unand/RSUP Dr. M. Djamil Padang

Korespondensi: Angela Lovena, Email: angelalovena@gmail.com, Telp: +6285355229999

\section{PENDAHULUAN}

Sirosis hepatis adalah penyakit hati kronik yang menyebabkan proses difus pembentukan nodul dan fibrosis. ${ }^{1}$ Prevalensi sirosis hepatis di dunia diperkirakan 100 (kisaran 25-100)/100.000 penduduk, 
tetapi hal tersebut bervariasi menurut negara dan wilayah. Sirosis hepatis menempati urutan ke-14 penyebab tersering kematian pada orang dewasa di dunia. $^{2,3}$ Menurut laporan rumah sakit umum pemerintah di Indonesia, rata-rata prevalensi sirosis hepatis adalah $3,5 \%$ dari seluruh pasien yang dirawat di bangsal Penyakit Dalam. ${ }^{4}$

Penyebab utama sirosis hepatis di negara barat adalah alkohol dan Hepatitis C, sedangkan di Indonesia penyebab utama sirosis hepatis adalah Hepatitis B (40\%-50\%) dan Hepatitis C (30\%-40\%). ${ }^{5}$

Sirosis hepatis secara klinis terbagi menjadi sirosis hepatis kompensata dan sirosis hepatis dekompensata, perubahan dari kompensata menjadi dekompensata disebabkan oleh insufisiensi sel hati dan hipertensi portal. $^{2,6} \mathrm{Hal}$ tersebut akan memengaruhi tes fungsi hati dan pemeriksaan hematologi, beberapa diantaranya yaitu kadar albumin, jumlah trombosit, dan kadar kreatinin. Albumin merupakan protein yang hanya disintesis di hati sehingga kadarnya akan memburuk sesuai perburukan hati. $^{5}$ Jumlah trombosit pada sirosis hepatis biasanya akan mengalami penurunan dan akan meningkatkan risiko perdarahan pada pasien sirosis hepatis. ${ }^{7}$ Pengukuran serum kreatinin dapat digunakan untuk menilai fungsi ginjal pada pasien sirosis hepatis ${ }^{8}$

Prognosis pasien sirosis hepatis dapat diperkirakan menggunakan klasifikasi Child Pugh, yang dibagi menjadi Child pugh $\mathrm{A}, \mathrm{B}$, dan $\mathrm{C}$ yang masing-masing mempunyai angka ketahanan hidup dua tahun sebesar $85 \%, 57 \%$, dan $35 \%{ }^{9}$

Komplikasi yang terjadi pada sirosis hepatis akan meningkatkan risiko kematian dan angka kesakitan pasien, komplikasi yang dapat terjadi adalah perdarahan saluran cerna, asites, sindrom hepatorenal, ensefalopati hepatik, peritonitis bakterial spontan dan karsinoma hepatoselular. ${ }^{2,6,10,11}$

Penelitian Patasik et al (2015) di RSUP Prof. Dr. D. Kandou Manado dari Agustus 2012-Agustus 2014, mendapatkan bahwa pasien sirosis hepatis terbanyak adalah laki-laki $(62,7 \%)$ dengan rentang usia terbanyak $50-59$ tahun $(31,4 \%)$, penyebab sirosis hepatis terbanyak adalah hepatitis B $(13,7 \%)$ dan komplikasi terbanyak varises esophagus $(23,5 \%) .{ }^{12}$
Penelitian yang dilakukan Tambunan et al di Di RSUP Dr. Soedarso Pontianak periode Januari 2008 Desember 2010 juga mendapatkan pasien sirosis hepatis terbanyak adalah laki-laki $(69,6 \%)$ dengan kelompok usia terbanyak adalah 50-59 tahun (31,0\%), penyebab terbanyak adalah hepatitis B $(43,5 \%)$, komplikasi terbanyak adalah perdarahan saluran cerna bagian atas (50\%), dan klasifikasi Child pugh terbanyak adalah Child pugh $\mathrm{C}(53,3 \%){ }^{13}$

Berdasarkan uraian di atas, perlu diteliti karakteristik pasien sirosis hepatis di RSUP Dr. M. Djamil Padang.

\section{METODE}

Penelitian ini merupakan studi deskriptif observasional dengan menggunakan data sekunder yang diambil dari rekam medik penderita sirosis hepatis yang dirawat di ruang rawat inap bagian IImu Penyakit Dalam di RSUP Dr. M. Djamil Padang pada periode 1 Januari 2011 - 31 Desember 2013.

Sampel penelitian ini adalah seluruh pasien sirosis hepatis yang memenuhi kriteria inklusi yaitu mempunyai catatan usia, jenis kelamin, pekerjaan, tingkat pendidikan dan hasil pemeriksaan laboratorium berupa tes serologi untuk hepatitis B dan hepatitis C, kadar albumin, jumlah trombosit, dan kadar kreatinin serum pada catatan rekam mediknya. Analis data yang digunakan adalah analisis univariat yang disajikan dalam bentuk tabel distribusi frekuensi

HASIL

Penelitian ini mendapatkan pasien yang memenuhi kriteria inklusi sebanyak 304 orang.

Tabel 1. Distribusi frekuensi pasien sirosis hepatis berdasarkan usia dan jenis kelamin

\begin{tabular}{lcc}
\hline \multicolumn{1}{c}{ Usia } & $\mathbf{f}$ & $\%$ \\
\hline$<31$ tahun & 13 & 4,3 \\
$31-40$ tahun & 35 & 11,5 \\
$41-50$ tahun & 78 & 25,7 \\
$51-60$ tahun & 107 & 35,2 \\
$61-70$ tahun & 42 & 13,8 \\
$>70$ tahun & 29 & 9,5 \\
$\quad$ Jenis Kelamin & & \\
Laki-laki & 200 & 65,8 \\
Perempuan & 104 & 34,2 \\
\hline
\end{tabular}


Tabel 1 memperlihatkan bahwa penderita sirosis hepatis terbanyak terdapat pada kelompok usia 51-60 tahun, yaitu sebanyak 107 orang $(35,2 \%)$ dan jenis kelamin terbanyak pada pasien sirosis hepatis adalah laki-laki dengan jumlah 200 orang (65,8\%) serta perbandingan laki-laki dan perempuan 1,9:1.

Tabel 2. Distribusi frekuensi pasien sirosis hepatis bedasarkan tingkat pendidikan dan pekerjaan

\begin{tabular}{lcc}
\hline \multicolumn{1}{r}{ Tingkat pendidikan } & $\mathbf{f}$ & $\%$ \\
\hline Pendidikan dasar & 154 & 50,7 \\
Pendidikan menengah & 126 & 41,4 \\
Pendidikan tinggi & 24 & 7,9 \\
Total & 304 & 100 \\
$\quad$ Pekerjaan & & \\
Pegawai & 51 & 16,8 \\
Wiraswasta & 41 & 13,8 \\
Petani / Nelayan / Buruh & 65 & 21,4 \\
Lainnya & 37 & 12,2 \\
Tidak bekerja & 109 & 35,8 \\
\hline Total & 304 & 100 \\
\hline
\end{tabular}

Tabel 2 memperlihatkan tingkat pendidikan pada pasien sirosis hepatis yang terbanyak adalah pendidikan dasar yaitu sebanyak 154 orang $(50,7 \%)$ dan pekerjaan terbanyak adalah pasien yang tidak bekerja yaitu 109 orang $(35,8 \%)$.

Tabel 3. Distribusi frekuensi pasien sirosis hepatis bedasarkan penyebab sirosis hepatis

\begin{tabular}{lcc}
\hline Penyebab Sirosis & $\mathbf{f}$ & $\mathbf{\%}$ \\
\hline Hepatitis B & 155 & 51,0 \\
Hepatitis C & 93 & 30,6 \\
Bukan hepatitis virus B/C & 56 & 18,4 \\
\hline Total & 304 & 100 \\
\hline
\end{tabular}

Tabel 3 memperlihatkan penyebab sirosis hepatis terbanyak yaitu Hepatitis B yang terjadi pada 155 orang $(51,0 \%)$.

Berdasarkan Tabel 4 dapat dilihat I hepatis adalah $<3,0 \mathrm{~g} / \mathrm{dl}$ sebanyak 217 orang $(71,4 \%)$, jumlah trombosit terbanyak adalah jumlah trombosit normal sebanyak 148 orang $(48,7 \%)$, dan kadar kreatinin terbanyak adalah kadar kreatinin normal sebanyak 233 orang $(76,6 \%)$.
Tabel 4. Distribusi frekuensi pasien sirosis hepatis bedasarkan kadar albumin, jumlah trombosit, dan kadar kreatinin serum

\begin{tabular}{lcc}
\hline Kadar Albumin & $\mathbf{f}$ & $\%$ \\
\hline$>3,5 \mathrm{~g} / \mathrm{dl}$ & 20 & 6,6 \\
$3,0-3,5 \mathrm{~g} / \mathrm{dl}$ & 67 & 22,0 \\
$<3,0 \mathrm{~g} / \mathrm{dl}$ & 217 & 71,4 \\
Total & 304 & 100 \\
Jumlah trombosit & & \\
$\quad$ Normal & 148 & 48,7 \\
$\quad$ Trombositopenia ringan & 88 & 28,9 \\
Trombositopenia sedang & 41 & 13,5 \\
$\quad$ Trombositopenia berat & 27 & 8,9 \\
Total & 304 & 100 \\
Kadar kreatinin serum & & \\
$\quad$ Normal & & \\
$\quad$ Abnormal & 233 & 76,7 \\
\hline Total & 71 & 23,3 \\
\hline
\end{tabular}

Tabel 5 memperlihatkan bahwa komplikasi yang paling sering terjadi pada pasien sirosis hepatis adalah asites yaitu sebanyak 218 orang (36,3\%).

Tabel 5. Distribusi frekuensi pasien sirosis hepatis bedasarkan komplikasi sirosis hepatis

\begin{tabular}{lcc}
\hline Komplikasi sirosis & $\mathbf{f}$ & $\mathbf{\%}$ \\
\hline Hematemesis dan/melena & 140 & 23,3 \\
Asites & 218 & 36,3 \\
Ensefalopati hepatik & 114 & 19,0 \\
Sindrom hepatorenal & 33 & 5,5 \\
Peritonitis bakterial spontan & 29 & 4,8 \\
Karsinoma hepatoselular & 67 & 11,1 \\
\hline Total & 601 & 100 \\
\hline
\end{tabular}

Tabel 6 memperlihatkan stage sirosis yang paling banyak adalah Child Pugh $\mathrm{C}$ dengan jumlah 183 orang $(60,3 \%)$.

Tabel 6 Distribusi frekuensi pasien sirosis hepatis bedasarkan klasifikasi Child Pugh

\begin{tabular}{lcc}
\hline Stage Sirosis Hepatis & $\mathbf{f}$ & $\%$ \\
\hline Child pugh A & 16 & 5,2 \\
Child Pugh B & 105 & 34,5 \\
Child Pugh C & 183 & 60,3 \\
\hline Total & 304 & 100 \\
\hline
\end{tabular}




\section{PEMBAHASAN}

Penelitian yang telah dilakukan mendapatkan penderita sirosis hepatis terbanyak ada pada kelompok usia 51-60 tahun, yaitu sebanyak 107 orang $(35,2 \%)$ dan kejadian terendah terdapat pada kelompok usia yang kurang dari 31 tahun (4,3\%). Hal tersebut sesuai dengan penelitian yang dilakukan oleh Marselina (2014) yang juga mendapatkan pasien sirosis hepatis terbanyak pada kelompok usia 51-60 tahun (34,3\%). ${ }^{14}$ Penelitian Patasik et al (2015) juga mendapatkan hal yang tidak jauh berbeda, yaitu penderita terbanyak ada pada kelompok usia 50-59 $(31,4 \%) .{ }^{12}$ Tambunan et al (2013) juga mendapatkan kelompok usia penderita sirosis hepatis yang paling banyak adalah $50-59$ tahun $(31,0 \%) .{ }^{13}$ Hal tersebut disebabkan karena sirosis hepatis adalah penyakit hati kronik yang bersifat laten sehingga sering dijumpai seiring bertambahnya usia dan perubahan patologis yang terjadi berkembang lambat sampai akhirnya gejala yang timbul menandakan terjadinya sirosis hepatis. Pasien dengan riwayat hepatitis, perubahan dari hepatitis kronik menjadi sirosis hepatis membutuhkan waktu sekitar 10 sampai 30 tahun sedangkan sirosis hepatis kompensata menjadi dekompensata biasanya membutuhkan waktu enam tahun. Penderita sirosis biasanya belum memeriksakan diri apabila gejala penyakitnya belum terlihat. $^{2,6}$

Penelitian ini mendapatkan pasien terbanyak adalah laki-laki yaitu 200 orang $(65,8 \%)$ dan perempuan 104 orang $(34,2 \%)$ dengan perbandingan laki-laki dan perempuan $1,9: 1$. Penelitian Daulay et al (2012) juga mendapatkan perbandingan penderita sirosis hepatis laki-laki dan perempuan adalah 1,9:1 dengan pasien laki-laki sebanyak $65,4 \%$ dan perempuan $34,6 \%{ }^{15}$ Penelitian Patasik et al (2015) juga mendapatkan penderita sirosis hepatis terbanyak yaitu laki-laki sebanyak $62,7 \%$ dan perempuan $37,3 \%{ }^{12}$ penelitian Tambunan et al (2013) juga mendapatkan hasil yang tidak jauh berbeda yaitu penderita laki-laki sebanyak $69,6 \%$ dan perempuan sebanyak 30,4\%, ${ }^{13}$ dan penelitian Marselina (2014) mendapatkan penderita laki-laki sebanyak $67,7 \%$ dan perempuan sebanyak $32,3 \% .{ }^{14}$ Jenis kelamin diperkirakan memiliki peranan pada terjadinya sirosis hepatis, laki-laki menpunyai lingkungan sosial dan gaya hidup yang berbeda dari perempuan, secara umum laki-laki memiliki peluang lebih besar untuk berkontak dengan virus hepatitis dan mengkonsumsi alkohol. ${ }^{16}$

Penelitian ini mendapatkan tingkat pendidikan terbanyak pada pasien sirosis hepatis adalah pendidikan dasar (SD, SMP, dan sederajat) 50,7\% kemudian pendidikan menengah (SMA dan sedejarat) $41,4 \%$ dan yang paling sedikit adalah pendidikan tinggi (perguruan tinggi) $7,9 \%$. Penelitian yang dilakukan Lamtota (2014) mendapatkan penderita dengan tingkat pendidikan SD dan SMP sebanyak $53 \%,{ }^{17}$ penelitian Daulay et al (2012) juga mendapatkan tingkat pendidikan tertinggi adalah SD dan SMP sebanyak $43,3 \% .^{15}$ Penelitian ini mendapatkan penderita sirosis hepatis menurun seiring dengan meningkatnya tingkat pendidikan pasien, hal tersebut kemungkinan disebabkan oleh kurangnya pengetahuan pasien tentang sirosis hepatis. Kesehatan dipengaruhi oleh berbagai faktor salah satunya adalah perilaku masyarakat, perilaku masyarakat tersebut akan dipengaruihi oleh pendidikan. Pengetahuan masyarakat tentang penyakit akan meningkat seiring dengan tingginya tingkat pendidikan dan sebaliknya, sehingga pencegahan terhadap penyakit lebih mungkin untuk dilakukan. $^{18}$

Penelitian ini mendapatkan distribusi frekuensi pasien sirosis hepatis berdasarkan pekerjaan yang terbanyak adalah pasien yang tidak bekerja (termasuk ibu rumah tangga) sebanyak 109 orang $(35,8 \%)$. Penelitian yang dilakukan Lamtota (2014) mendapatkan pekerjaan terbanyak adalah wiraswasta sebanyak 29,4\%, ${ }^{17}$ Samila (2012) mendapatkan pekerjaan terbanyak adalah karyawan sebanyak $37,7 \%,{ }^{19}$ dan Malau (2013) mendapatkan pekerjaan yang terbanyak adalah petani sebanyak $51,3 \%{ }^{20}$ Penelitian mengenai karakteristik pekerjaan pada pasien sirosis hepatis mendapatkan hasil yang berbeda-beda, kemungkinan disebabkan oleh mayoritas pasien yang datang berobat juga berbeda. Masyarakat yang berisiko tinggi untuk tertular virus hepatitis adalah pasien hemodialisa, orang yang kontak serumah dengan penderita hepatitis atau karier 
hepatitis dan pekerja di bidang kesehatan terutama yang kontak dengan darah. ${ }^{6}$ Penelitian ini mendapatkan pekerjaan pada pasien sirosis hepatis terbanyak adalah yang tidak bekerja, kelompok ini didominasi oleh ibu rumah tangga yang kemungkinan besar terkena sirosis hepatis karena tertular virus hepatitis dari orang terdekatnya.

Penyebab sirosis hepatis terbanyak adalah hepatitis B sebanyak 155 orang (51,0\%). Patasik (2015) juga mendapatkan hepatitis B sebagai penyebab terbanyak yaitu $37,3 \%,^{12}$ Lamtota (2014) juga mendapatkan penyebab sirosis hepatis terbanyak adalah hepatitis $\mathrm{B}$ dengan jumlah $57,8 \%,{ }^{17}$ dan Marselina (2014) mendapatkan hepatitis B sebagai penyebab sirosis hepatis terbayak dengan jumlah $60,7 \% .{ }^{14}$ Penyebab sirosis hepatis yang utama di Indonesia adalah hepatitis B dan hepatitis C, virus hepatitis B menyebabkan sirosis hepatis sekitar $40 \%-50 \%$ virus hepatitis C $30 \%-40 \%$, dan $10 \%-20 \%$ penyebab lainnya, seperti alcohol, nonalcoholic fatty liver disease, sirosis biliaris dan lain-lain. ${ }^{5}$

Penelitian ini mendapatkan kadar albumin terbanyak pada pasien sirosis hepatis adalah pasien dengan kadar albumin kurang dari 3,0 g/dl (71,4\%). Hal ini sesuai dengan penelitian Budiyasa et al (2011) yang juga mendapatkan pasien terbanyak dengan kadar albumin kurang dari $3 \mathrm{~g} / \mathrm{dl}$ sebanyak $91,8 \%{ }^{21}$ Albumin adalah protein yang hanya disintesis di jaringan hati dan kadarnya menurun sesuai perburukan sirosis hepatis sehingga menyebabkan hipoalbuminenia. ${ }^{5}$ Perbedaan kadar albumin pada pasien sirosis hepatis kemungkinan disebabkan oleh perbedaan tingkat keparahan pasien yang dirawat, penelitian ini sendiri mendapatkan pasien sirosis hepatis didominasi oleh pasien dengan tingkat penyakit yang sudah lanjut, terbukti dengan klasifikasi sirosis hepatis terbanyak adalah Child C, dan terdapatnya pasien dengan kadar albumin normal kemungkinan disebabkan karena sirosis yang diderita pasien tersebut masih dalah fase kompensata (Child pugh $A)^{22}$

Penelitian yang telah dilakukan mendapatkan jumlah trombosit terbanyak pada pasien sirosis hepatis adalah pasien dengan jumlah trombosit normal sebanyak 148 orang (48,7\%). Penelitian Andriana
(2013) mendapatkan pasien yang mengalami trombositopenia sebanyak $49 \%$ dan pasien dengan trombosit normal sebanyak $51 \% .{ }^{23}$ Penelitian Juliana dan Wibawa (2006) mendapatkan pasien sirosis hepatis dengan trombosit normal sebanyak 25,6\%, trombositopenia sedang $41,0 \%$, trombositopenia ringan $28,2 \%$, dan trombositopenia berat $5,1 \%{ }^{24}$ Trombositopenia adalah kelainan hematologi yang sering terjadi pada sirosis hepatis, secara teoritis trombositopenia terjadi sampai $76 \%$ pada pasien sirosis hepatis, tetapi berbagai penelitian yang pernah dilakukan mempublikasikan trombositopenia berada pada kisaran $15 \%-70 \%$ pada sirosis hepatis dan trombositopenia sedang terjadi sekitar $13 \%$ pada pasien sirosis hepatis. Terjadinya trombositopenia disebabkan oleh berbagai faktor yaitu terjadinya splenomegali, terganggunya produksi trombosit di sumsum tulang, dan penurunan pembentukan trombopoetin. ${ }^{7}$ Jumlah trombosit pada pasien sirosis hepatis dapat normal, hal ini disebabkan karena jumlah trombosit di darah tergantung kemampuan sumsum tulang untuk memproduksi trombosit. ${ }^{25}$

Penelitian yang telah dilakukan mendapatkan pasien sirosis hepatis dengan kadar kreatinin normal sebanyak $76,6 \%$ dan pasien dengan kadar kreatinin abnormal sebanyak $23,2 \%$. Pada sirosis hepatis kadar kreatinin biasanya akan rendah karena kreatinin merupakan hasil metabolisme kreatin pada otot, sehingga nilai kreatinin dipengaruhi oleh massa otot dan pada pasien sirosis hepatis sering terjadi penurunan massa otot, akan tetapi jika nilai kreatinin serum yang meningkat di atas normal menandakan adanya gangguan fungsi ginjal pada pasien sirosis. Kadar kreatinin pada pasien sirosis hepatis dapat normal, meskipun pembentukan kreatinin berkurang, hal tersebut terjadi jika laju filtrasi glomerulus sangat rendah. ${ }^{2,8}$ Kadar kreatinin sebenarnya kurang dapat diandalkan dan tidak sensitif untuk menilai fungsi ginjal, oleh karena itu lebih baik menggunakan estimasi laju filtrasi glomerulus. Salah satu cara untuk menilai estimasi laju filtrasi glomerulus adalah menggunakan persamaan Cockcroft-Gault. Persamaan ini membutuhkan data usia, jenis kelamin, berat badan dan kadar kreatinin pasien. ${ }^{26}$ 
Komplikasi penderita sirosis hepatis terbanyak adalah asites yaitu sebanyak $36,3 \%$ dan urutan kedua adalah hematamesis dan/melena sebanyak 23,2\%. Penelitian Malau (2013) mendapatkan komplikasi sirosis hepatis terbanyak adalah varises esofagus sebanyak $35,7 \%{ }^{20}$ Tambunan et al (2013) mendapatkan bahwa komplikasi terbanyak adalah perdarahan saluran cerna bagian atas sebanyak $50 \%{ }^{13}$ Penelitian Imelda (2012) mendapatkan komplikasi tersering pada pasien sirosis hepatis adalah asites sebanyak $88,7 \% .{ }^{27}$ Secara teoritis asites adalah komplikasi yang paling sering terjadi pada sirosis hepatis. Asites merupakan akibat dari hipertensi portal dan hipoalbuminemia pada sirosis hepatis. $^{5}$ Ada $70 \%$ pasien sirosis hepatis akan mengalami varises esofagus, pecahnya varises ini dapat menyebabkan hematemesis dan/ melena yang terjadi sampai $25 \%$ pada pasien sirosis hepatis. ${ }^{6}$

Klasifikasi Child Pugh terbanyak berdasarkan penelitian yang telah dilakukan peneliti pada pasien sirosis hepatis adalah Child pugh $\mathrm{C}$, yaitu sebanyak 69,3\%. Penelitian Saksana et al (2012) juga mendapatkan kalsifikasi Child pugh C yang tertinggi yaitu sebanyak 49,3\%. ${ }^{28}$ Penelititan Tambunan (2013) mendapatkan pasien dengan Child pugh $\mathrm{C}$ sebanyak $53,3 \% .{ }^{13}$ Marselina (2014) juga mendapatkan pasien sirosis terbanyak dengan Child pugh $\mathrm{C}$, yaitu $61,5 \%{ }^{14}$ Pasien sirosis hepatis di RSUP Dr. M. Djamil Padang yang terbanyak adalah pasien dengan klasifikasi Child pugh $\mathrm{C}$, hal ini menandakan bahwa pasien yang datang berobat sebagian besar dengan derajat penyakit yang sudah berat. Sirosis hepatis adalah penyakit yang bersifat laten, dibutuhkan waktu bertahun-tahun sampai akhirnya gejala yang timbul menandakan terjadinya sirosis hepatis, selama masa laten tersebut akan terjadi kemunduran fungsi hati secara bertahap namun pasien tidak menyadarinya dan belum memeriksakan diri dengan berobat. ${ }^{2,6}$

\section{SIMPULAN}

Kelompok usia pasien sirosis hepatis di RSUP

Dr. M. Djamil Padang yang terbanyak adalah kelompok usia 51-60 tahun.

Jenis kelamin pasien sirosis hepatis di RSUP

Dr. M. Djamil Padang yang terbanyak adalah laki-laki.
Tingkat pendidikan pasien sirosis hepatis di RSUP Dr. M. Djamil Padang yang terbanyak adalah tingkat pendidikan dasar.

Pekerjaan pasien sirosis hepatis di RSUP Dr. M. Djamil Padang yang terbanyak adalah penderita yang tidak bekerja.

Penyebab terbanyak pada pasien sirosis hepatis di RSUP Dr. M. Djamil Padang adalah Hepatitis B.

Kadar albumin pasien sirosis hepatis di RSUP Dr. M. Djamil Padang yang terbanyak adalah kadar albumin kurang dari 3,0 g/dl.

Jumlah trombosit pasien sirosis hepatis di RSUP Dr. M. Djamil Padang yang terbanyak adalah jumlah trombosit normal.

Kadar kreatinin pasien sirosis hepatis di RSUP Dr. M. Djamil Padang yang terbanyak adalah kadar kreatinin normal.

Komplikasi terbanyak pasien sirosis hepatis di RSUP Dr. M. Djamil Padang adalah asites.

Klasifikasi Child Pugh pasien sirosis hepatis di RSUP Dr. M. Djamil Padang yang terbanyak adalah Child pugh $\mathrm{C}$.

\section{UCAPAN TERIMA KASIH}

Terima kasih kepada semua pihak yang telah membantu dalam pelaksanaan penelitian. Kepada Direktur Umum RSUP Dr. M Djamil padang yang telah memberikan izin melaksanakan penelitian dan kepada staf bagian rekam medik yang telah membantu penulis dalam melaksanakan penelitian.

\section{DAFTAR PUSTAKA}

1. McCormick PA. Hepatic cirrhosis. Dalam: Dooley JS, Lok AS, Burroungs AK, Heathcote EJ, editor (penyunting). Sherlock's Deseases of the Liver and Billiary System. Edisi ke-12. USA: Wiley-Blackwell; 2011. hlm.103-20.

2. Tsao GG. Cirrhosis and its sequel. Dalam: Goldman L, editor (penyunting). Goldman's Cecil Medicine. Edisi ke-24. Philadelphia: Elsevier; 2012. hlm.999-1007.

3. Tsochatzhis EA, Bosch J, Burroughs AK. Liver cirrrhosis. The Lancet. 2014;383(9930):1749-61. 
4. PPHI (Perhimpunan Peneliti Hati Indonesia). Sirosis hati [serial online] 2013. (diunduh 1 Maret 2015). Tersedia dari: URL: HYPERLINK http://pphionline.org/alpha/?p=570

5. Nurdjanah S. Sirosis hati. Dalam: Sudoyo AW, Setiyohadi B, Alwi I, Simadibrata M, Setiati S editor (penyunting). Buku ajar ilmu penyakit dalam jilid 1. Edisi ke-4. Jakarta: Balai Penerbit FKUI; 2006. hlm.445-8.

6. Lindseth GN. Gangguan hati, kandung empedu, dan pangkreas. Dalam: Hartanto P, Wulansari ND, A Mahanani, editor (penyunting). Patofisiologi Konsep Klinis Proses-Proses Penyakit. Jakarta: EGC; 2005. hlm. 472-508.

7. Afdhal N, McHutchison J, Brown R, Jacobson I, Manns M, Poordad F, et al. Trombocytopenia associated with chronic liver disease. Journal of Hepatology. 2008;48(6):1000-7.

8. Gines $P$, Schrier RW. Renal flailure in cirrhosis. The New England Journal of Medicine. 2009;361:1279-90.

9. Chung V. Systemic Therapy for Hepatocellular Carcinoma and Cholangiocarcinoma. Surgical Oncology Clinics. 2015;24(1):187-98.

10. Setiawan PB, Kusumobroto H. Sindrom Hepatorenal. Dalam: Sudoyo AW, Setiyohadi B, Alwi I, Simadibrata M, Setiati S, editor (penyunting). Buku ajar ilmu penyakit dalam jilid 1 Edisi ke-4. Jakarta: Balai Penerbit FKUI; 2006. hlm.454-5.

11. Budihusodo U. Karsinoma hati. Dalam: AW Sudoyo AW, Setiyohadi B, Alwi I, Simadibrata $M$, Setiati $S$, editor (penyunting). Buku ajar ilmu penyakit dalam Jilid 1. Edisi ke-4. Jakarta: Balai Penerbit FKUI; 2006. hIm.457-61.

12. Patasik YZ, Waleleng BJ, Wantania F. Profil pasien sirosis hati yang dirawat inap di RSUP Prof. Dr. D. Kandou Manado periode Agustus 2012 sampai Agustus 2014. Eclinic. 2015;3(1):342-7.

13. Tambunan A, Mulyadi Y, Kahtan MI. Karakteristik pasien sirosis hati di RSUP Dr. Soedarso Pontianak periode Januari 2008 - Desember 2010. Jurnal Mahasiswa PSPD FK Universitas Tanjungpura. 2013;2(1):1-19.
14. Marselina NMT. Gambaran Klinis Pasien Sirosis Hati: Studi Kasus di RSUP Dr Kariadi Semarang Periode 2012-2012. Jurnal Media Medika Muda. 2014;3(1).

15. Daulay AZ, Harahap A, Hiswani. Karakteristik penderita sirosis hati yang dirawat inap di RS Haji Medan tahun 2000-2002 [serial online] 2012 (diunduh 5 September 2015). Tersedia dari: URL: HYPERLINK http://repository.usu.ac.id/handle/ $123456789 / 34036$

16. Shimizu I, Matsumoto T, Suzuki N, Sagara C, Koizumi $\mathrm{Y}$, Asaki $\mathrm{T}$, et al. Chronic liver disease develop more slowly in females than males. Dalam: Simizu I, editor (penyunting). Preventive female sex factors against the development of chronic liver disease. Japan: Bentham eBooks; 2012. hlm.3-18.

17. Lamtota I. Profil pasien sirosis hati yang dirawat inap di RSUP Haji Adam Malik Medan [serial online] 2014 (diunduh 5 Mei 2015). Tersedia dari: URL: HYPERLINK http://repository.usu.ac.id/ handle/123456789/40085

18. Lubis AF. Ekonomi kesehatan. Medan: USU press; 2009.

19. Samila Y. Karakteristik penderita sirosis hati rawat inap di rumah sakit Tembakau Deli PTP. Nusantara II Medan Tahun 1999-2003 [serial online] 2012 (diunduh 5 Mei 2015). Tersedia dari: URL: HYPERLINK http://repository.usu.ac.id/ handle/123456789/32533

20. Malau DL. Karakteristik penderita sirosis hati yang dirawat di RSUD Sidikalang tahun 2007-2011 (serial online) 2013 (diunduh 5 Mei 2015). Tersedia dari: URL: HYPERLINK http://repository.usu.ac.id/ handle/123456789/38147

21. Budiyasa DGA, Ariawan Y, Mariadi IK, Wibawa IDN, Purwadi N, Syuryadarma IGA. Correlation betweet serum albumin level and degree of esophageal varices in patients with liver cirrhosis. The journal of gastroenterology, hepatology, and digestive endoscopy. 2011;12(1):22-7.

22. Sutcliffe RP, Antoniades CG, Deshpande R, Tucker ON, Heaton N. Liver and pancreatobiliary surgery with liver transplantation. Oxford: Oxford University Press; 2010. 
23. Andriana Y. Hubungan trombositopenia, hipoalbuminemia, dan splenomegali sebagai prediktor varises esofagus pada pasien sirosis hati di RSUD Dr. Soedarso Pontianak. Jurnal Mahasiswa PSPD Universitas Tanjungpura. 2013;2(1):1-19.

24. Juliana IM, Wibawa IDN. Korelasi antara derajat penyakit sirosis hati berdasarkan klasifikasichildturcotte-pugh dengan konsentrasi trombopoietin serum. J Penyakit Dalam. 2008;9(1):23-35.

25. Witters P, Freson K, Verslype C, Peerlinck K, Hoylaerts M, Nevens F, et al. Blood platelet number and function in chronic liver disease and cirrhosis. Alimentary Pharmacology \& Therapeutics. 2009;27(11):1017-29.
26. Noble E, Johnson DW. Automated laboratory reporting of estimated glomerular filtration rate: is good for the health of patients and their doctors. Biochemia Medica. 2007;17(1):16-28.

27. Imelda R. Profil pasien sirosis hati di ruang rawat inap penyakit dalam RSUP H. Adam Malik Medan [ serial online] 2012 (diunduh 5 Mai 2015) Tersedia dari: URL: HYPERLINK http://repository.usu.ac.id/ handle/123456789/33680

28. Saksana RA, Bayupurnama $P$, Indrawati F, Ratnasari N, Madusena S, Triwikatmani C, et al. Correlation between the severity of liver cirrhosis (child-pugh score) and QTc interval prolongation. The Indonesian Journal of Gastroenterology, Hepatology and Digestive Endoscopy. 2012;13(3):150-60. 